\title{
Total Synthesis of Pumiliotoxins 209F and 251D via Late-Stage, Nickel-Catalyzed Epoxide-Alkyne Reductive Cyclization
}

\author{
Katrina S. Woodin and Timothy F. Jamison* \\ Department of Chemistry, Massachusetts Institute of Technology, Cambridge, Massachusetts, \\ 02139
}

\begin{abstract}

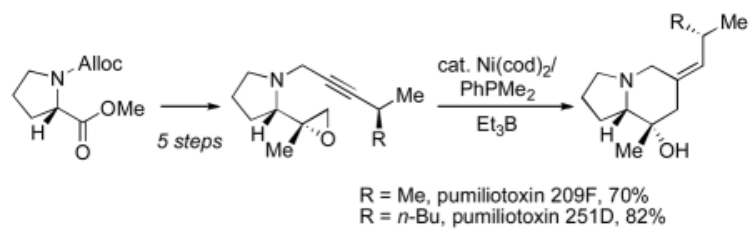

Pumiliotoxins 209F and 251D were synthesized using highly selective nickel-catalyzed epoxidealkyne reductive cyclizations as the final step. The exocyclic $(Z)$-alkene found in the majority of the pumiliotoxins was formed stereospecifically and regioselectively, without the use of a directing group on the alkyne, and the epoxide underwent ring opening exclusively at the less hindered carbon to provide the requisite tertiary alcohol. The epoxides were prepared using diastereoselective addition of a sulfoxonium anion to a proline-derived methyl ketone.
\end{abstract}

The pumiliotoxins were first isolated in 1967 from the Dendrobates pumilio frogs in South America. ${ }^{\mathrm{i}, \mathrm{ii}}$ The structure and stereochemistry of these alkaloids were initially established via X-ray crytallographic analysis of the hydrochloride salt of pumiliotoxin 251D (1) ${ }^{\mathrm{iii}}$ and confirmed by total syntheses of several members of this family of natural products. iv,v,vi,vii $^{\text {in }}$ Thirty pumiliotoxins have a $(Z)$-6-alkylideneindolizidine ring system and a tertiary alcohol at C8.

Several different strategies have been developed for the synthesis of the ubiquitous $(Z)$ alkene. Overman used an iminium ion-vinylsilane cyclization to this end in the first total synthesis of pumiliotoxin $251 \mathrm{D}^{6 \mathrm{a}}$ and later employed a related iodide-promoted, iminium ion-alkyne cyclization to synthesize more complex pumiliotoxins., ${ }^{4}$ viii Gallagher used a stereospecific elimination of a $\beta$-hydroxylactam to install the ( $Z$ )-alkene in the synthesis of pumiliotoxin 251D. ${ }^{6 \mathrm{~b}}$ In the synthesis described herein, we have reduced the construction of the pumiliotoxins to simultaneous and stereospecific installation of the exocyclic $Z$-alkene and tertiary alcohol present in the final step of the synthesis.

Our strategy is based on the notion that both of these challenges could be addressed by nickel-catalyzed reductive cyclizations ${ }^{\text {ix }}$ of epoxy-alkynes previously developed in our laboratory (Figure 1). ${ }^{\mathrm{x}}$ However, all of the epoxides in our earlier investigations were monosubstituted (terminal). Thus a major question in the context of the pumiliotoxins was whether or not 1,1-disubstituted epoxides (e.g., 3a and $\mathbf{3 b}$ ), which we had previously found to be recalcitrant substrates, would undergo reductive cyclization. ${ }^{\mathrm{xi}}$ Furthermore, in order to

tfj@mit.edu.

Supporting Information Available: Experimental procedures and full spectroscopic data for all new compounds. This material is available free of charge via the Internet at http://pubs.acs.org. 
be used as the final step, the regioselectivity of both alkyne addition and epoxide ringopening could not depend upon the use of a directing group on the alkyne. Nevertheless, proline-derived ketones $\mathbf{4 a}$ and $\mathbf{4 b}$ and propargyl bromides $\mathbf{5 a}$ and $\mathbf{5 b}$ were attractive precursors and readily available. Accordingly, we began our investigations by preparing these intermediates via chiral ketones $\mathbf{4 a}$ and $\mathbf{4 b}$.

Treatment of carbamate-protected proline methyl esters $\mathbf{6} \mathbf{a}$ and $\mathbf{6} \mathbf{b}^{\mathrm{xii}}$ with $N, O-$ dimethylhydroxylamine hydrochloride and trimethylaluminium afforded Weinreb amides 7a and $\mathbf{7 b}$, respectively, in good yield (Scheme 1). Conversion of these amides to ketones $\mathbf{4 a}$ and $\mathbf{4 b}$ proceeded in a similarly straightforward manner, setting the stage for investigation of the step that would set the stereogenic center corresponding to the tertiary alcohol in the natural products. ${ }^{\text {iiii }}$

Application of the Corey-Chaykovsky ${ }^{x i v}$ sulfur-ylide epoxidation method provided stereochemically complementary results, depending on which sulfonium reagent was employed. ${ }^{\mathrm{Xv}}$ When Cbz-protected ketone $\mathbf{4 a}$ was subjected to dimethylsulfonium methylide, the undesired diastereomer (epoxide 8a) was formed with high selectivity (>10:1 dr) in good yield, but both diastereomers were optically inactive, suggesting rapid racemization of the proline-derivative prior to a highly diastereoselective epoxide formation. Gratifyingly, when dimethyloxosulfonium methylide was used, the desired diastereomer (8a) was afforded in good yield and in a highly diastereoselective fashion (>10:1 dr). It was further discovered that the carbamate group was required to impart the high diastereoselectivity during the epoxidation, as other proline-derived ketones gave a 1:1 mixture of diastereomers. ${ }^{\text {vi }}$ The dimethylsulfonium methylide reagent often exhibits kinetic control of stereoselectivity. In a Felkin-Ahn analysis of the reaction at hand, the nucleophile would approach anti to the carbamate group, leading to the observed diastereomer (8a, undesired). Conversely, diastereoselective dimethylsulfoxonium methylide addition reactions tend to be under thermodynamic control. Epoxide 8a (desired) may thus be favored under these conditions because of the reversible nature of the addition process and a greater thermodynamic stability of either a subsequent intermediate or of $\mathbf{8 a}$ itself. ${ }^{\text {xvii }}$

Attempts to remove the $\mathrm{Cbz}$ group from epoxide 8a unfortunately led to a complex mixture of products under all conditions evaluated. We thus turned our attention to the Alloc series and found that the conditions that provided high dr in the $\mathrm{Cbz}$ series $(\mathrm{NaH}$, trimethylsulfoxonium chloride) gave similar results with Alloc-protected ketone $\mathbf{4 b}$. However, although the desired product had formed with high diastereoselectivity, it was optically inactive, suggesting that racemezation of ketone $\mathbf{4 b}$ had occurred prior to the epoxidation. A careful examination of reagents and reaction conditions revealed that the racemization could be prevented by the use of $n$ - $\mathrm{BuLi}$ (instead of $\mathrm{NaH}$ ) at a lower reaction temperature (Scheme 3). ${ }^{\text {xviii }}$ This sequence provided epoxide $\mathbf{8 b}$ with high diastereoselectivity and optical purity. Removal of the Alloc group was effected with catalytic $\mathrm{Pd}(\mathrm{dba})_{2}$ and dppb in the presence of excess diethylamine. ${ }^{\mathrm{xix}}$ The free amine was treated with propargyl bromide $\mathbf{5} \mathbf{a}^{\mathrm{xx}}\left(\mathrm{Na}_{2} \mathrm{CO}_{3}\right.$ /acetone) to form epoxy-alkyne $\mathbf{3 a}$, thus setting the stage for the critical nickel-catalyzed step.

Under reaction conditions routinely used in intermolecular nickel-catalyzed coupling reactions between alkynes and terminal epoxides, ${ }^{9}$ no conversion of epoxy-alkyne substrate 3a was observed (Table 1, entry 1). However, conducting the reaction in the absence of an additional solvent did lead to the formation of small amounts of the desired product, pumiliotoxin $209 \mathrm{~F}$ (2). The largest increase in yield was imparted by conducting the reaction at slightly elevated temperature (entry 3). By lowering the amount of $\mathrm{Et}_{3} \mathrm{~B}$ to $150 \mathrm{~mol} \%$, which also considerably increased the concentration of the reaction, the yield appreciated further (entry 4). The phosphine employed also had a dramatic effect on the yield. The larger 
tricyclopentylphosphine $\left(\mathrm{PCyp}_{3}\right)$ was inferior to tributylphosphine $\left(\mathrm{PBu}_{3}\right)$, and the smaller $\mathrm{PMe}_{2} \mathrm{Ph}$ was superior to all phosphines evaluated (entries 5 and 6). ${ }^{\mathrm{xxi}}$,xxii,xxiii Under the optimum conditions the nickel-catalyzed reductive cyclization of epoxy-alkyne 2a proceeded in $70 \%$ yield to produce pumiliotoxin $209 \mathrm{~F}$ (2).

In addition to representing the first example of a successful nickel-catalyzed cyclization between a 1,1-disubstituted epoxide and an alkyne, a noteworthy element of selectivity was that the six-membered ring was formed exclusively. The other alkyne addition regioisomer would have led to a seven-membered ring containing an alkene. This isomer was not observed, likely because cis addition to the alkyne, a process that occurs with very high fidelity, would lead to a highly strained trans alkene in the seven-membered ring as the carbon-carbon bond formed. In a similar vein, no evidence of epoxide opening at the more hindered carbon, which would lead to a five-membered ring, was observed. We believe that the sense of epoxide-opening regioselectivity is largely dictated by this difference in steric hindrance, and it is also possible that the Ni complex reacts with the epoxide first, which in turn classifies addition to the alkyne as a 6-exo-dig cyclization. ${ }^{\mathrm{X}}$

To investigate the utility and scope of this cyclization further and to take advantage of the high degree of convergence in this strategy, pumiliotoxin 251D (1) was also synthesized. Substitution of the appropriate propargyl electrophile for $\mathbf{5 a}$ (Scheme 3) would provide the necessary educt for the nickel-catalyzed reductive cyclization. In other words, after preparation of propargyl bromide $\mathbf{5 b},{ }^{\text {xxiv }}$ only two new transformations would be required to convert a known intermediate in the 209F synthesis to pumiliotoxin 251D.

The route to pumiliotoxin 251D thus began with synthesis of alcohol 10 from aldehyde $\mathbf{9}^{\mathrm{xxv}}$ using the Corey-Fuchs reaction (Scheme 4). ${ }^{x x v i}$ This alcohol was converted to bromide $\mathbf{5 b}$, and epoxide $\mathbf{3 b}$ was afforded by alkylation of the primary amine prepared previously.

As was the case in the pumiliotoxin 209F studies, the final step of the 251D synthesis, nickel-catalyzed reductive cyclization of epoxy-alkyne $\mathbf{3 b}$ proceeded smoothly, affording the natural product in $82 \%$ yield as a single diastereomer and regioisomer (Scheme 5).

In summary, pumiliotoxin $209 \mathrm{~F}$ was synthesized in seven steps (longest linear sequence) in $25 \%$ overall yield, and pumiliotoxin 251D was synthesized in nine linear steps from commercial materials in $17 \%$ overall yield. Both syntheses utilized a novel cyclization reaction, an intramolecular, nickel-catalyzed reductive coupling of a 1,1-disubstituted epoxide and an alkyne. In this way the tertiary homoallylic alcohol and exocyclic trisubstituted alkene moieties present in this family of natural products were prepared in the final step of each total synthesis. For these reasons, this strategy shows promise for entry into other members of the pumiliotoxin family by way of a common intermediate.

\section{Experimental Section}

\section{(S)-Allyl 2-((R)-2-methyloxiran-2-yl)pyrrolidine-1-carboxylate (8b)}

$\mathrm{Me}_{3} \mathrm{SOCl}(0.096 \mathrm{~g}, 0.75 \mathrm{mmol})$ was dissolved in THF $(7 \mathrm{~mL})$ and $n \mathrm{BuLi}(0.22 \mathrm{~mL}, 0.55$ $\mathrm{mmol}, 2.5 \mathrm{M}$ in hexanes) was added dropwise at $\mathrm{rt}$. The reaction was stirred at $\mathrm{rt}$ for $4.5 \mathrm{~h}$, then cooled to $-20{ }^{\circ} \mathrm{C}$ and the slurry was added to the ketone $4 \mathbf{b}(0.099 \mathrm{~g}, 0.5 \mathrm{mmol})$, dissolved in THF ( $2 \mathrm{~mL})$, dropwise via cannula over $20 \mathrm{~min}$. The reaction was stirred at -20 ${ }^{\circ} \mathrm{C}$ for $32 \mathrm{~h}$ and quenched with $0.1 \mathrm{M} \mathrm{NaHSO}_{4}(10 \mathrm{~mL}) .{ }^{7}$ The aqueous layer was extracted with ethyl acetate $(3 \times 10 \mathrm{~mL})$, and the organic extracts were washed with brine $(50 \mathrm{~mL})$, and dried over $\mathrm{Na}_{2} \mathrm{SO}_{4}$. The solution was filtered and concentrated in vacuo, and was purified by flash column chromatography (3:7 EtOAc:hexanes) to give alloc-protected epoxide $\mathbf{8 b}$ (0.076 g, 72\% yield, 91:9 dr favoring desired diastereomer, $>98 \%$ ee, as 
determined by chiral GC). $\mathrm{R}_{f} 0.41$ (1:1 EtOAc:hexanes). ${ }^{1} \mathrm{H}$ NMR $\left(500 \mathrm{MHz}, \mathrm{CDCl}_{3}\right.$ ) (reported as $\sim 1: 1$ mixture of rotamers) $\delta 5.97-5.90(\mathrm{~m}, 2 \mathrm{H}), 5.31(\mathrm{dd}, J=10.4,1.1 \mathrm{~Hz}, 2 \mathrm{H})$, $5.20(\mathrm{dd}, J=10.4,1.1 \mathrm{~Hz}, 2 \mathrm{H}), 4.68-4.52(\mathrm{~m}, 4 \mathrm{H}), 4.06(\mathrm{~d}, J=6.4 \mathrm{~Hz}, 1 \mathrm{H}), 3.94(\mathrm{~d}, J=6.4$ $\mathrm{Hz}, 1 \mathrm{H}), 3.62-3.28(\mathrm{~m}, 4 \mathrm{H}), 2.63(\mathrm{~d}, J=4.6 \mathrm{~Hz}, 2 \mathrm{H}), 2.53(\mathrm{~d}, J=4.6 \mathrm{~Hz}, 2 \mathrm{H}), 2.10-1.67$ $(\mathrm{m}, 8 \mathrm{H}), 1.35(\mathrm{~s}, 3 \mathrm{H}), 1.33(\mathrm{~s}, 3 \mathrm{H}) .{ }^{13} \mathrm{C}$ NMR $\left(125 \mathrm{MHz}, \mathrm{CDCl}_{3}\right)$ (reported as $\sim 1: 1$ mixture of rotamers) $\delta 155.6,155.3,133.3,117.5,117.4,65.9,59.5,59.0,52.6,52.4,47.7,47.2$, 29.0, 27.8, 24.6, 23.9, 19.9, 19.6. IR (thin film NaCl) 3057, 2980, 2882, 1702, 1648, 1405, 1350, 1335, 1277, 1186, 1121, 1098, 919, $774 \mathrm{~cm}^{-1}$. HRMS (ESI) $\mathrm{m} / z$ 234.1105 [M+Na; calcd for $\mathrm{C}_{11} \mathrm{H}_{17} \mathrm{NO}_{3}$ : 234.1101]. $[\alpha]_{\mathrm{D}}=-80.8\left(23{ }^{\circ} \mathrm{C}, 589 \mathrm{~nm}, 0.45 \mathrm{~g} / 100 \mathrm{~mL}, \mathrm{CHCl}_{3}\right)$.

\section{(S)-2-((R)-2-methyloxiran-2-yl)-1-(4-methylpent-2-ynyl)pyrrolidine (3a)}

$\operatorname{Pd}(\mathrm{dba})_{2}(0.086 \mathrm{~g}, 0.15 \mathrm{mmol})$ and dppb $(0.064 \mathrm{~g}, 0.15 \mathrm{mmol})$ were combined in a glove box. Alloc-protected epoxide $8 \mathbf{b}(0.317 \mathrm{~g}, 1.5 \mathrm{mmol})$ in THF $(4 \mathrm{~mL})$ was added followed by addition of diethylamine $(2.3 \mathrm{~mL}, 22.5 \mathrm{mmol})$. The reaction was stirred at $\mathrm{rt}$ for $2 \mathrm{~h}$, then filtered through a plug of celite with ether $(10 \mathrm{~mL})$ to removed the palladium catalyst and was concentrated in vacuo to form free amine. The amine was dissolved in acetone $(15 \mathrm{~mL})$ and $\mathrm{Na}_{2} \mathrm{CO}_{3}(0.398 \mathrm{~g}, 3.75 \mathrm{mmol})$ and propargyl bromide $\mathbf{5 a}(0.290 \mathrm{~g}, 1.8 \mathrm{mmol})$ were added, and the reaction was allowed to stir at $\mathrm{rt}$ for $16 \mathrm{~h}$. The solvent was removed in vacuo, and the compound was purified by flash column chromatography using a solvent gradient (1:19 to 3:7 EtOAc:hexanes) to give amine 3a as a pale yellow oil $(0.17 \mathrm{~g}, 55 \%$ yield over the two steps, 91:9 dr retained). $\mathrm{R}_{f} 0.51$ (1:1 EtOAc:hexanes). ${ }^{1} \mathrm{H}$ NMR $\left(500 \mathrm{MHz}, \mathrm{CDCl}_{3}\right)$ (reported as a 10:1 mixture of diastereomers, asterisk denotes minor diastereomer): $\delta 3.60$ $(\mathrm{dd}, J=16.7,1.9 \mathrm{~Hz}, 1 \mathrm{H}), 3.49 *(\mathrm{dd}, J=16.7,1.9 \mathrm{~Hz}, 0.1 \mathrm{H}), 3.41 *(\mathrm{dd}, J=16.7,1.9 \mathrm{~Hz}$, $0.1 \mathrm{H}), 3.31(\mathrm{dd}, J=16.7,1.9 \mathrm{~Hz}, 1 \mathrm{H}), 3.08(\mathrm{t}, J=7.3 \mathrm{~Hz}, 1 \mathrm{H}), 2.96^{*}(\mathrm{t}, J=7.3 \mathrm{~Hz}, 0.1 \mathrm{H})$, $2.77 *(\mathrm{~d}, J=5.3 \mathrm{~Hz}, 0.1 \mathrm{H}), 2.62-2.48(\mathrm{~m}, 4 \mathrm{H}), 2.27(\mathrm{t}, J=7.33 \mathrm{~Hz}, 1 \mathrm{H}), 1.89-1.70(\mathrm{~m}$, $4 \mathrm{H}), 1.33(\mathrm{~s}, 3 \mathrm{H}), 1.29 *(\mathrm{~s}, 0.3 \mathrm{H}), 1.60(\mathrm{~d}, J=6.9 \mathrm{~Hz}, 6 \mathrm{H}) 1.15^{*}(\mathrm{~d}, J=6.9 \mathrm{~Hz}, 0.6 \mathrm{H}) .{ }^{13} \mathrm{C}$ NMR (125 MHz, $\mathrm{CDCl}_{3}$ ) (major and minor peaks reported) $\delta 91.2,90.4,74.7,73.9,66.8$, 65.4, 58.1, 57.4, 54.0, 53.5, 53.2, 51.0, 42.6, 41.8, 28.4, 27.8, 23.6, 23.5, 23.3, 23.1, 20.8, 20.7, 16.8, 16.7. IR (thin film NaCl) 3035, 2969, 2873, 2813, 2242, 1462, 1444, 1400, 1368, $1319,1180,1123,1095,1067,909 \mathrm{~cm}^{-1}$. HRMS (ESI) $\mathrm{m} / \mathrm{z} 208.1695$ [M+H; calcd for $\left.\mathrm{C}_{13} \mathrm{H}_{21} \mathrm{NO}: 208.1696\right] .[\alpha]_{\mathrm{D}}=-40.4\left(23{ }^{\circ} \mathrm{C}, 589 \mathrm{~nm}, 0.2 \mathrm{~g} / 100 \mathrm{~mL}, \mathrm{CHCl}_{3}\right)$.

\section{Pumiliotoxin 209F (2)}

In a glovebox, $\mathrm{Ni}(\mathrm{cod})_{2}(5.6 \mathrm{mg}, 0.02 \mathrm{mmol})$ and $\mathrm{PMe}_{2} \mathrm{Ph}(5.7 \mu \mathrm{L}, 0.04 \mathrm{mmol})$ were placed into an oven-dried, sealed tube, which was sealed with a rubber septum and teflon cap. The tube was removed from the glovebox, placed under argon, and triethylborane $(22 \mu \mathrm{L}, 0.15$ $\mathrm{mmol}$ ) was added via syringe. The resulting solution was stirred $5 \mathrm{~min}$, and the epoxyalkyne 3a (21 $\mathrm{mg}, 0.10 \mathrm{mmol})$ was added dropwise via microsyringe. The reaction was heated to $65{ }^{\circ} \mathrm{C}$ and allowed to stir $16 \mathrm{~h}$. The solution was then cooled to rt, and ether (2 $\mathrm{mL}$ ) was added to dilute the solution at which point the septum was removed and the reaction was stirred 30 min open to air to promote quenching of the catalyst. The crude mixture was purified by flash chromatography on silica gel using a solvent gradient (1:49 to 1:19 $\left.\mathrm{MeOH}: \mathrm{CHCl}_{3}\right)$ to give pumiliotoxin $209 \mathrm{~F}(\mathbf{2})$ as a colorless oil $(14.6 \mathrm{mg}, 70 \%$ yield, 1 diastereomer). $\mathrm{R}_{f} 0.33$ (1:9 MeOH:CHCl 3$)^{1} \mathrm{H}$ NMR $\left(500 \mathrm{MHz}, \mathrm{CDCl}_{3}\right) \delta 5.11$ (d, $J=9.2$ $\mathrm{Hz}, 1 \mathrm{H}), 3.80(\mathrm{~d}, J=11.9 \mathrm{~Hz}, 1 \mathrm{H}), 3.07(\mathrm{t}, J=8.3 \mathrm{~Hz}, 1 \mathrm{H}), 2.67(\mathrm{~s}, 1 \mathrm{H}), 2.60-2.55(\mathrm{~m}, 1 \mathrm{H})$, $2.36(\mathrm{~d}, J=11.9 \mathrm{~Hz}, 1 \mathrm{H}), 2.24-2.20(\mathrm{~m}, 1 \mathrm{H}), 2.12(\mathrm{~d}, J=13.8 \mathrm{~Hz}, 1 \mathrm{H}), 2.09(\mathrm{~d}, J=13.8$ $\mathrm{Hz}, 1 \mathrm{H}), 1.98$ (t, $J=5.0 \mathrm{~Hz}, 1 \mathrm{H}), 1.79-1.65(\mathrm{~m}, 4 \mathrm{H}), 1.14$ (s, 3H), 0.99 (d, $J=6.7 \mathrm{~Hz}, 3 \mathrm{H})$, $0.92(\mathrm{~d}, J=6.7 \mathrm{~Hz}, 3 \mathrm{H}) .{ }^{13} \mathrm{C} \mathrm{NMR}\left(125 \mathrm{MHz}, \mathrm{CDCl}_{3}\right) \delta 135.8,129.4,71.9,68.6,54.6$, 53.1, 48.9, 26.96, 24.5, 23.7, 23.6, 23.4, 21.3. IR (thin film NaCl) 3512, 2959, 2874, 2785, 2743, 1464, 1445, 1424, 1396, 1376, 1321, 1309, 1297, 1275, 1216, 1175, 1150, 1098, 967 $\mathrm{cm}^{-1}$. HRMS (ESI) $\mathrm{m} / \mathrm{z} 210.1852\left[\mathrm{M}+\mathrm{H}\right.$; calcd for $\left.\mathrm{C}_{13} \mathrm{H}_{23} \mathrm{NO}: 210.1849\right] .[\alpha]_{\mathrm{D}}=-12.8(23$ $\left.{ }^{\circ} \mathrm{C}, 589 \mathrm{~nm}, 0.3 \mathrm{~g} / 100 \mathrm{~mL}, \mathrm{CHCl}_{3}\right)$. 


\section{Pumiliotoxin 251 D (1)}

Same experimental procedure as $2 . \mathrm{R}_{f} 0.30\left(1: 9 \mathrm{MeOH}: \mathrm{CHCl}_{3}\right) .{ }^{1} \mathrm{H}$ NMR $(500 \mathrm{MHz}$, $\left.\mathrm{CDCl}_{3}\right) \delta 5.04(\mathrm{~d}, J=9.5 \mathrm{~Hz}, 1 \mathrm{H}), 3.78(\mathrm{~d}, J=12.0 \mathrm{~Hz}, 1 \mathrm{H}), 3.07-3.03(\mathrm{~m}, 1 \mathrm{H}), 2.67(\mathrm{~s}$, $1 \mathrm{H}), 2.42-2.30(\mathrm{~m}, 1 \mathrm{H}), 2.34(\mathrm{~d}, J=12.0 \mathrm{~Hz}, 1 \mathrm{H}), 2.25-2.15(\mathrm{~m}, 1 \mathrm{H}), 2.15-2.12(\mathrm{~m}, 2 \mathrm{H})$, $2.00-1.90(\mathrm{~m}, 1 \mathrm{H}), 1.78-1.60(\mathrm{~m}, 4 \mathrm{H}), 1.32-1.10(\mathrm{~m}, 6 \mathrm{H}), 1.14(\mathrm{~s}, 3 \mathrm{H}), 0.97(\mathrm{~d}, J=6.5 \mathrm{~Hz}$, $3 \mathrm{H}), 0.87(\mathrm{t}, J=6.9 \mathrm{~Hz}, 3 \mathrm{H}) .{ }^{13} \mathrm{C} \mathrm{NMR}\left(125 \mathrm{MHz}, \mathrm{CDCl}_{3}\right) \delta 134.7,130.0,71.8,68.4,54.7$, $53.3,48.9,37.6,32.2,29.8,24.4,23.3,22.9,21.8,21.2,14.2$. IR (thin film NaCl) 3418 , 2982, 2909, 2872, 1660, 1465, 1420, 1324, 1305, 1291, 1176, 1121, 1072, 939, 913, 871 $\mathrm{cm}^{-1}$. HRMS (ESI) $\mathrm{m} / z 252.2321\left[\mathrm{M}+\mathrm{H}\right.$; calcd for $\mathrm{C}_{16} \mathrm{H}_{29} \mathrm{NO}$ : 252.2322]. $[\alpha]_{\mathrm{D}}=-9.3(23$ ${ }^{\circ} \mathrm{C}, 589 \mathrm{~nm}, 0.05 \mathrm{~g} / 100 \mathrm{~mL}, \mathrm{CHCl}_{3}$ ).

\section{Supplementary Material}

Refer to Web version on PubMed Central for supplementary material.

\section{Acknowledgments}

This work was supported by the National Institutes of General Medical Sciences (GM-063755). We are grateful to Ms. Li Li for obtaining mass spectrometric data for all compounds (MIT Department of Chemistry Instrumentation Facility, which is supported in part by the NSF (Grants CHE-9809061 and DBI-9729592) and the NIH (Grant 1S10RR13886-01).

\section{References}

1. Daly JW, Myers CW. Science. 1967; 156:970-973. [PubMed: 6023266]

2. For a recent review of pumiliotoxins, see: Daly JW, Spande TF, Garraffo HM. J Nat Prod. 2005; 68:1556-1575. [PubMed: 16252926]

3. Daly JW, Tokuyama T, Fujiwara T, Highet RJ, Karle IL. J Am Chem Soc. 1980; 102:830-836.

iv. For a review of pumiliotoxin syntheses, see: Franklin AS, Overman LE. Chem Rev. 1996; 96:505522. [PubMed: 11848762]

v. Total syntheses of pumiliotoxin 209F: (a) Overman LE, Lesuisse D. Tetrahedron Lett. 1985; 26:4167-4170.(b) Kibayashi C, Aoyagi S. Synth Org Chem, Jpn. 1999; 57:981-992.8-Epipumiliotoxin 209F: (c) Sudau A, Münch W, Bats JW, Nubbemeyer U. Eur J Org Chem. 2002:3315-3325.

vi. Total syntheses of pumiliotoxin 251D: (a) Overman LE, Bell KL. J Am Chem Soc. 1981; 103:1851-1853.(b) Fox DNA, Lathbury D, Mahon MF, Molloy KC, Gallagher T. J Am Chem Soc. 1991; 113:2652-2656.Racemic 251D: (c) Bargar TM, Lett RM, Johnson PL, Hunter JE, Chang CP, Pernich DJ, Sabol MR, Dick MR. J Agric Food Chem. 1995; 43:1044-1051.(d) See also ref. $5 \mathrm{c}$.

vii. Formal syntheses of pumiliotoxins: (a) Honda T, Hoshi M, Kanai K, Tsubuki M. J Chem Soc, Perkin Trans. 1994; I:2091-2101.(b) Cossy J, Cases M, Pardo DG. Synlett. 1996:909-910.(c) Barrett AGM, Damiani F. J Org Chem. 1999; 64:1410-1411.(d) Martin SF, Bur SK. Tetrahedron. 1999; 55:8905-8914.(e) Ni Y, Zhao G, Ding Y. J Chem Soc, Perkin Trans. 2000; 1:3264-3266.(f) Wang B, Fang K, Lin GQ. Tetrahedron Lett. 2003; 44:7981-7984.

viii. Overman LE, Sharp MJ. Tetrahedron Lett. 1988; 29:901-904.

ix. In the syntheses of several allopumiliotoxins, Montgomery utilized a diastereoselective nickelcatalyzed alkyne-aldehyde reductive cyclization to establish the (Z)-alkene and the configuration of a secondary alcohol: (a) Tang XQ, Montgomery J. J Am Chem Soc. 1999; 121:6098-6099.(b) Tang XQ, Montgomery J. J Am Chem Soc. 2000; 122:6950-6954.Review: (c) Montgomery J. Angew Chem. 2004; 43:3890-3908. [PubMed: 15274210]

x. Molinaro C, Jamison TF. J Am Chem Soc. 2003; 125:8076-8077. [PubMed: 12837057]

xi. Molinaro C, Jamison TF. unpublished results.

xii. (a) Cbz-Pro methyl ester is commericially available. Alloc-Pro methyl ester was prepared in quantitative yield from Pro methyl ester and allyl chloroformate, see: Yamada Y, Takahashi W, 
Asada Y, Holiuchi J, Takeda K, Harigaya Y. Chem Pharm Bull. 2004; 52:1082-1085. [PubMed: 15340193]

xiii. Epimerization of ketones $4 \mathrm{a}$ and $4 \mathrm{~b}$ was not observed (chiral GC analysis).

xiv. Corey EJ, Chaykovsky M. J Am Chem Soc. 1965; 87:1353-1364.

$\mathrm{xv}$. For a discussion on kinetic vs. thermodynamic control in sulfur ylide addition reactions, see: Johnson CR, Schroeck CW, Shanklin JR. J Am Chem Soc. 1973; 95:7424-7431.

xvi. For a discussion on sulfur-ylide epoxidation of similar pyrrolidines, see: Fray MJ, Thomas EJ, Wallis JD. J Chem Soc, Perkin Trans. 1983; I:395-401.

xvii. For a discussion of substrate control in sulfur-ylide epoxidations, see Li H-H, Dai L-X, Aggarwal VK. Chem Rev. 1997; 97:2341-2372. [PubMed: 11848902] and references cited therein.

xviii. Racemization could also be prevented by using less $\mathrm{NaH}(150 \mathrm{~mol} \%)$ and by lowering the reaction temperature, but conversion to product was much slower. See Supporting Information for details.

xix. Genêt JP, Blart E, Savignac M, Lemeune S, Lemaire-Audoire S, Bernard JM. Synlett. 1993:680682.

xx. Propargyl bromide 5a was prepared by treatment of 4-methylpent-2-yn-1-ol with $\mathrm{CBr}_{4}$ and $\mathrm{PPh}_{3}$ in $\mathrm{CH}_{2} \mathrm{Cl}_{2}$. See Supporting Information for details.

xxi. Other phosphine ligands evaluated include $\mathrm{P}(n \text {-octyl })_{3}, \mathrm{P}(\text { o-anisyl })_{3}, \mathrm{P}\left(\mathrm{CH}_{2} \mathrm{CH}_{2} \mathrm{CN}\right)_{3}, \mathrm{P}(\mathrm{OEt}) \mathrm{Ph}_{2}$, $\mathrm{P}(\mathrm{OEt})_{2} \mathrm{Ph}$, and $\mathrm{P}(\mathrm{OEt})_{3}$.

xxii. The cone angles of $\mathrm{PBu}_{3}$ and $\mathrm{PMe}_{2} \mathrm{Ph}$ are $132^{\circ}$ and $122^{\circ}$, respectively: Rahman MM, Liu HY, Eriks K, Prock A, Giering WP. Organometallics. 1989; 8:1-7.

xxiii. van Leeuwen PWNM, Kamer PCJ, Reek JNH, Dierkes P. Chem Rev. 2000; 100:2741-2770. [PubMed: 11749304]

xxiv. Preparation of bromide 5b: Okamoto S, Iwakubo M, Kobayashi K, Sato F. J Am Chem Soc. 1997; 119:6984-6990.

xxv. Synthesis of aldehyde 9 in 56\% yield over four steps: Goldstein SW, Overman LE, Rabinowitz MH. J Org Chem. 1992; 57:1179-1190.

xxvi. Corey EJ, Fuchs PL. Tetrahedron Lett. 1972; 13:3769-3772.

J Org Chem. Author manuscript; available in PMC 2011 August 1. 
<smiles>[R]C(C)C=C1CN2CCC[C@]2(C)[C@](C)(O)C1</smiles>

$\mathrm{R}=n$-Bu, pumiliotoxin 251D (1) $\mathrm{R}=\mathrm{Me}$, pumiliotoxin 209F (2)

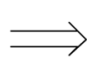<smiles>[R]N1CCC[C@H]1C(C)=O</smiles>

4a: $\mathrm{R}^{\prime}=\mathrm{Cbz}$

4b: $R^{\prime}=$ Alloc<smiles>[R]C(C)C#CCN1CCC[C@@]1(C)[C@]1(C)CO1</smiles>

3a: $\mathrm{R}=\mathrm{Me}$

3b: $\mathrm{R}=n-\mathrm{Bu}$<smiles>[R]C(C)C#CCBr</smiles>

$5 a: R=M e$

5b: $\mathrm{R}=n-\mathrm{Bu}$

Figure 1.

Retrosynthetic Analysis of the Pumiliotoxins. 
<smiles>[R]N1CCC[C@H]1C(=O)OC</smiles>

6a: $R^{\prime}=\mathrm{Cbz}$

6b: $R^{\prime}=$ Alloc

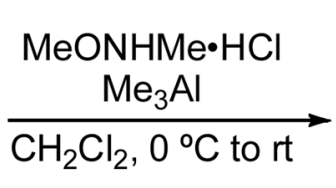

7a: $R^{\prime}=\mathrm{Cbz}, 75 \%$

$7 \mathrm{~b}: \quad \mathrm{R}^{\prime}=$ Alloc, $95 \%$<smiles>[R]N1CCC[C@@]1(C(=O)O)C(=O)N(C)OC</smiles>

Scheme 1.

Synthesis of Proline-Derived Ketone 4 


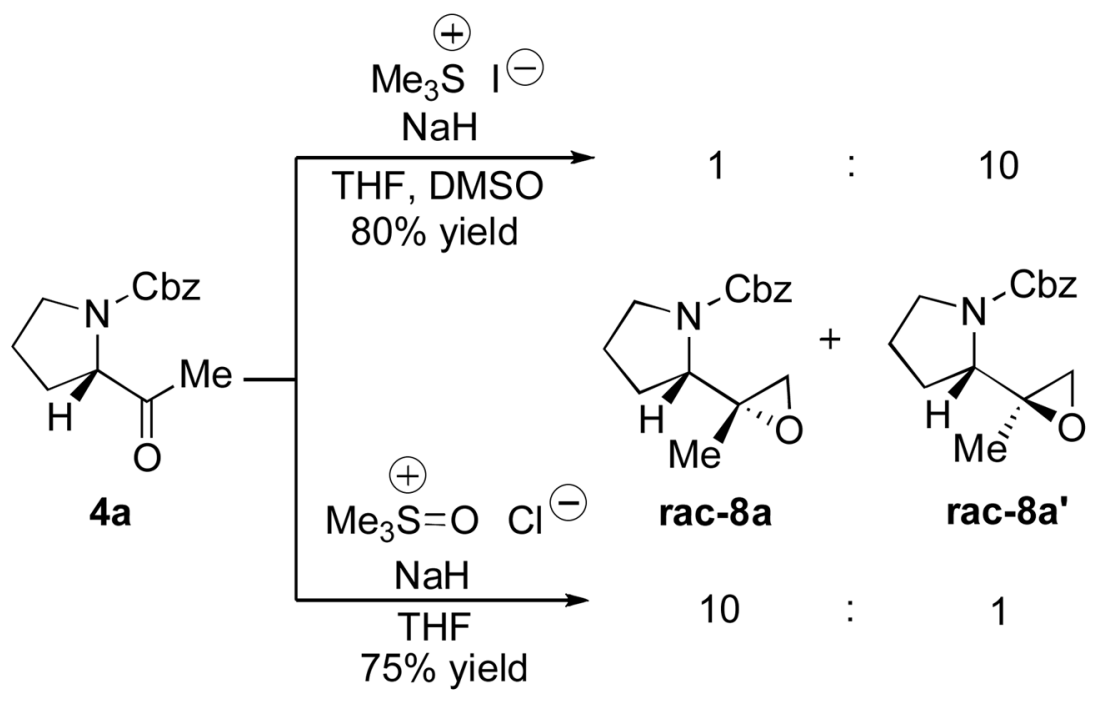

Scheme 2. 


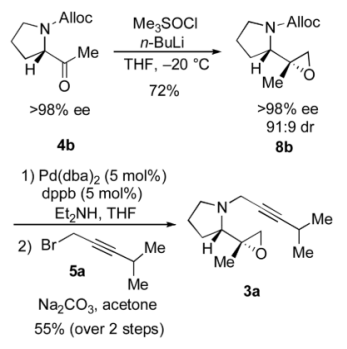

Scheme 3.

Synthesis of Epoxy-Alkyne 3a (209F Precursor) 


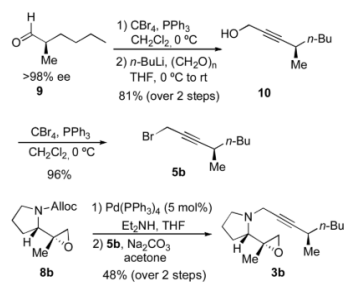

Scheme 4.

Synthesis of Epoxy-Alkyne 3b (251D Precursor) 


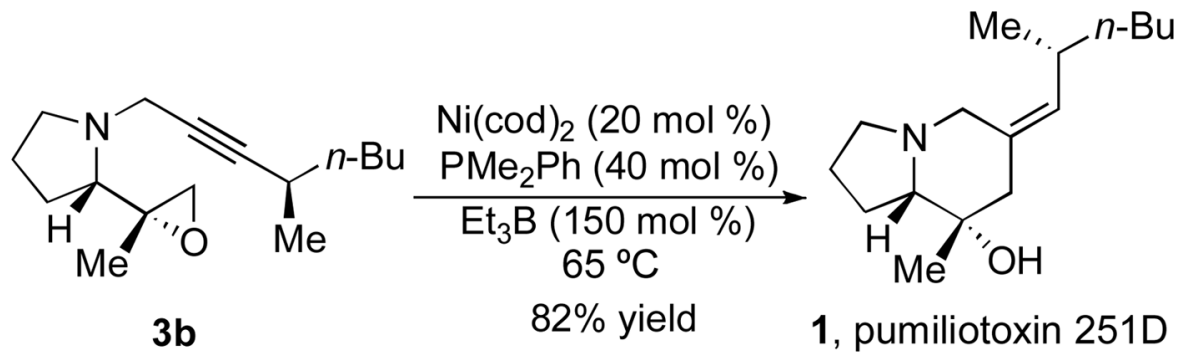

Scheme 5.

Synthesis of Pumiliotoxin 251D via Nickel-Catalyzed Reductive Cyclization 
